\title{
The Present Situation of Scientific Research in Private College and Improving Countermeasures
}

\author{
Yi ZHU, Qingling LIAO*, Chun LIU, Xiuying WANG, Heai ZENG, Min WANG \\ Wuhan Technology and Business University, Electronic Commerce College, Hubei Wuhan 430065
}

\begin{abstract}
Private colleges and universities have become an important part of higher education system in China, the scientific research work is the basic way to the construction of private university teaching staff, to improve the quality of education and teaching and to serve to the society, but most scientific research work in private colleges and universities is still at the initial stage, which is not commensurate with its status in the higher education. This article puts forward the countermeasures to improve the scientific research work by analyzing the current situation and reasons of scientific research in private colleges and universities.
\end{abstract}

KEYWORD: Private colleges and universities; Scientific Research; promoting countermeasure

With the China's talent demand for high-speed economy development and people's growing demand, higher education was rapid development in China in the recent 30 years. As of July 9, 2014, there are 2246 colleges and universities, in which 444 are private college, private college have become an important part of higher education system in China.

Scientific research as a whole and full range of thinking training activity can effectively improve the private college teachers' thinking ability, enrich their knowledge structure, so as to improve the teaching ability. Scientific research can stimulate the internal vitality, optimize educational mode, improve the quality of education and teaching, the school running level and competitiveness will continue to improve and enhance. At present, the majority of private college scientific research work is still at the initial stage, which is not commensurate with its status in the higher education.

\section{THE STATUS OF SCIENTIFIC RESEARCH WORK IN PRIVATE COLLEGE}

\subsection{Management departments and private college do not attach importance, teachers' scientific research consciousness is weak}

Private college school running time is short, the scientific research strength cannot compete with the public institutions, while most of the government management departments use the same evaluating standard to treat all the school, the development of private college scientific research lag behind, which is not fully taken into the overall management of government departments.

Private college is mainly running by the social strength investment, there is a tendency of focusing on teaching, but looking down on scientific research guiding ideology. They think of private college is positioning on application technology. Teaching is the center, the assessment of teachers is focusing on teaching and the teaching workload finished. School work forms the phenomenon that classroom teaching is a hard task while scientific research is a soft index.

Private college teachers have weak scientific research consciousness and have a psychological fear of scientific research work. They think that as long as they do well in the work of teaching is enough, while the scientific research needs solid foundation and advanced theory. In addition, there are many obstacles in the achievement evaluation for teachers, which further weakened their enthusiasm and confidence of scientific research.

Zhu Yi (1977-), male, master, lecturer, Wuhan Technology and Business University, Wuhan 430071, The 2013 scientific research special project (S2013006): the current situation and countermeasures of the scientific research work of private colleges and universities in Hubei. *Corresponding author 


\subsection{Take few scientific subjects, and obtain less scientific research funds}

Considering various aspects of the situation, except a few schools, private college can rarely obtain the scientific research project approval of the competent administrative department. With the 2014 National Social Science Fund youth project as an example, the project number is 1044 , private college projects number are not more than 5. In the national level scientific research fund of surface projects and key projects, the private colleges' project is very rare. The longitudinal research projects obtained are generally instructional projects without funds to support.

As to the scientific research funds, due to longterm quota declaration system of scientific research project, each project funds grants basically has been planned to determine the allocation to certain schools. Due to the limited teaching force and the scientific research strength, private college obtain the approved projects for the vast majority are self-financing projects.

\subsection{Few achievements in scientific research, and low conversion rate}

Nationwide, except part of the achievements published by Zhejiang Shuren University, Huanghe Science and Technology College and other few earlier set up colleges with their own journal have some influence, most private college publish few scientific research achievements.

For fewer achievements and lack of influence, scientific achievements of private college can rarely win awards. The existing research achievements are mainly concentrated in the low input, less timeconsuming field of Humanities and Social Science and Education Teaching, few in Natural Science and Technology Application, basically no Technology Innovation, scientific research conversion rate is very low.

\section{THE REASONS FOR THE WEAK LEVEL OF PRIVATE COLLEGES AND UNIVERSITIES SCIENTIFIC RESEARCH}

\subsection{The faculty structure is irrational, has not formed a scientific research team}

Teacher is the main force in scientific research, but the faculty structure in private college is irrational, not forming a teaching staff with the combination of teaching and scientific research. Young teachers in private college account for more than $60 \%$ of the total number of teachers, young teachers for not solid enough theory foundation, lack of scientific research experience, cannot carry out scientific research work independently in the short term. The elder professor employed from public universities energy is limited, and lack of momentum and force to engaged in scientific research. The middle-aged teachers with a very small proportion are the pillar of the school teaching and scientific research, who are difficult to spare a large amount of time and energy to do research work. The irrational talent structure is an important factor to influence the scientific research work.

The young teachers need a leader to guide them to carry on the scientific research work, the elder professor's scientific research ability is strong, but the scientific research leading and guiding role is not fully play. Due to the lack of middle aged leading figures who can play a leading role with senior title, the elder professor's research role of "transmit, aid and lead " does not play out, so that private college have not formed a scientific research team, which is difficult to effectively enhance the scientific research ability and level.

\subsection{Scientific research investment of private college is less, and with fewer funding channels}

The scientific research work must have funds to support, while private college is insufficient in research funds contribution generally, the main reason is that the channel of research funding is less. Private college scientific research work is not included in the unified management of scientific research departments, while public universities annually through the declaration of various scientific research projects to get a considerable number of scientific research funds, but private college can only obtain instructional project by self-financing.

It is difficult to obtain longitudinal research project funds, some private college are trying to obtain transverse scientific research funds through schoolenterprise cooperation. Because the research foundation of is not perfect, scientific theory focuses more on summary of practical experience, and the guidance to practice and develop predictive function has not been fully released, scientific research achievements conversion rate is relatively lower, it has not achieved major breakthrough.

Private college funds mainly depend on the students tuition fee, campus construction, teaching staff construction, daily teaching and other school funding has been considerable, scientific research investment is relative lack. The vast majority of private college are teaching-oriented, they do not pay 
enough attention to the scientific research work, do not want to invest more money for scientific research. Therefore, to carry out scientific research work in private college is severely constrained by funds.

\subsection{The management ability of scientific research is weak, and the condition of scientific research foundation is poor}

Private college has not yet formed a set of management system and mechanism suitable to the development of scientific research. First is the management institutions are not perfect, lack of professional management institutions or full-time management workers, it is difficult to guarantee the normal work from the organization construction. Second is the scientific research management system is not perfect and not standardized, it basically lacks of clear regulation and management on research projects, funds application, evaluation, reward and punishment system and the files management aspects. These have restricted the further development of scientific research work.

Compared with the public university, the private college creation starts late, with low starting point, which are generally facing the difficulties of lack of funds, the teaching and research facilities are not perfect, scientific research basis conditions are poor, the environment of scientific research have to be improved. Although a part of the developed more mature private colleges have certain teaching facilities and scientific research conditions, they are also hard to ensure the smooth development of scientific research work.

\section{THE IMPROVING COUNTERMEASURES FOR PRIVATE COLLEGE SCIENTIFIC RESEARCH WORK}

\subsection{Optimize the faculty structure, establish scientific research team}

Private college have less full-time teachers mostly, the majority are newly graduated students, most teachers lack of scientific research experience, the teachers' scientific research ability needs to be improved, there is an urgent need to establish a scientific research team in adaptation to scientific research work. There are a variety of ways to understand the details, it can be based on the statistics and sorting of the achievements in scientific research of personnel, to basically grasp the overall level, then to select the teachers in the prime of life, with the sense of responsibility and work enthusiasm as the core force of scientific research.

Private college should give full play to the role of old professors to guide, train, and improve the young teachers' scientific research ability. In the process of engaging in research, teachers should timely carry out scientific research knowledge training, individual guidance. It's easy to realize the complementary advantages, to improve irrational conditions of scientific research structure.

In order to promote the formation of an outstanding scientific research group, management institutions can provide scientific research conditions, take measures, strengthen the support to scientific research backbone, and create a good atmosphere for scientific research. The management institutions should regularly hold some collective study and discussion activities, actively organize backbone to participate in academic conferences. In addition, onthe-job self-improvement is also an effective way to improve the level of scientific research. We should vigorously promote and encourage self-study and cooperation for teachers to combine their teaching practice. In short, College should grasp the construction of scientific research team with the innovative ideas, to make scientific research backbone stand out, and to establish a scientific research team in adapt to the need of scientific research work in private college as soon as possible.

\subsection{Promote collaborative innovation, increase investment in scientific research}

Private college are in a disadvantageous position in scientific research innovation, mainly for the innovation achievements of scientific research are few and have not formed its own research strengths, and have not established their own strong discipline. The main reasons are the lack of a number of full-time scientific research innovation teacher team with high efficiency and competence, a serious shortage of scientific research funds, and the apparent lack of foreign academic exchange and teaching practice of the teachers.

"2011 plan" is the new opportunity for the development of private college. We should change the idea and update the concept, put the collaborative innovation in the strategic position for the school's future development; should build a strong discipline and create own research team; should vigorously invest funds into the scientific research, amply reward teachers with innovation achievements. Scientific research innovation is the most important driving force in the formation and improvement of the core 
competitiveness of private college which is related to the future development. Therefore, only when private college attach great importance and practice collaborative innovation, that they can form their own core competitiveness, stand in an invincible position in the future, and even integrate into the first-class universities list.

Taking Hubei Province as an example, almost every private college has approved a provincial cooperative innovation project, the annual funds allocation is 2 million, continuous support for 4 years, and require the school according to 1:1 supporting scientific research funds. This is the first time that a private college won the provincial finance charge investment in research funds, if the private college approved of the cooperative innovation project can give full play to the role of 8000000 scientific research funds in 4 years, and actively support funds for scientific research according to the requirements, to promote collaborative innovation between college and scientific research institutes, enterprises and government, it will raise to a new stage in scientific research.

\subsection{Strengthen scientific research management, implement assessment incentive}

Private college should to set up the corresponding scientific research management institutions, which are in charge of the school related scientific research management. College should establish the University Academic Committee to preside over and guide the scientific research institutions at all levels, it carry out scientific research on the theory and practice problems, it is responsible for the scientific research planning, plan implementation, funds raising, project application, achievement assessment, information release work. College could establish classified teaching-research subject office to do well in the teacher subject declaration, statistics, sorting, filing, it is responsible for the preliminary assessment and identification of scientific research achievement of teachers.

Private college should make full use of the flexible mechanism, strong market sensitivity, strong strain capacity and other advantages to improve the industry management system closely combining full-time scientific research management institutions and technology and market economy, College should establish efficient scientific research management team to perfect the corresponding management system, including the scientific research assessment, reward and punishment, achievement promotion and scientific research filing system.
Private college should innovate science and technology management mechanism and set up new input mechanism. They should formulate science and technology preferential policy to increase its input efforts. They can establish scientific research funds to use for the school scientific research project study, $\mathrm{PhD}$ and Professor talent introduction start-up funds, monograph publication funds, provinces and cities research projects and high-tech research projects supporting funds etc. They can establish relevant scientific research reward measures according to the actual situation, for example to establish the corresponding reward standard and methods for national, provincial, municipal and other different levels of achievements, and also to give some rewards to the monograph publication and all levels of academic journals.

Private college should establish new mechanism on talent introduction, cultivation and development. It should pay attention to whether it is scientific and reasonable. In the introduction of high level talents, it not only need to formulate preferential policies, to give a certain tilt on wages, family work arrangement, and housing, but also need to create standing out working conditions for them. At the same time they should strengthen the training of young talents, create conditions for them to grow up, so that they are able to work independently. They should attract talent with mechanism, move talent with passion, and keep talents with career.

Private college should establish scientific assessment system and use scientific research achievement as one of the indicators of teachers' work assessment to implement high quality best reward performance-related payment system. They should establish talent competition and incentive mechanism. They can reform the personnel system, the income distribution system and benefit distribution system and clear reward and punishment, it's fair and reasonable to improve the innovation of scientific research.

\section{REFERENCES}

[1] Fu Guohui. On the status of college and university scientific research in discipline construction. Journal of Jiangxi Electric Power Vocational Technology College, 2010, (2): 66-68.

[2] Li Qinhua. The main problems in universities scientific research management and the countermeasures. Tech Information Development \& Economy, 2008, (19): 267-268.

[3] Zhang Jinfeng, The status and trends of China's higher education reform and development. Journal of Zhejiang Shuren University, 2007 (3). 